\title{
Functional and radiological outcome of proximal femoral nailing versus dynamic hip screw in unstable intertrochanteric femur fractures
}

\author{
Kushal Nikhil Parikh", Chintan Parmar ${ }^{2}$, Mitesh Patel ${ }^{1}$, Shalin Bharat Shah ${ }^{1}$
}

\author{
${ }^{1}$ Department of Orthopaedics, Surat Municipal Institute of Medical Education and Research, Surat, Gujarat, India \\ ${ }^{2}$ Consultant Orthopaedic Surgeon, Tricolour Hospital, Vadodara, Gujarat, India
}

Received: 22 September 2018

Revised: 17 October 2018

Accepted: 18 October 2018

\author{
*Correspondence: \\ Dr. Kushal Nikhil Parikh, \\ E-mail: kushalparikh@yahoo.com
}

Copyright: (c) the author(s), publisher and licensee Medip Academy. This is an open-access article distributed under the terms of the Creative Commons Attribution Non-Commercial License, which permits unrestricted non-commercial use, distribution, and reproduction in any medium, provided the original work is properly cited.

\begin{abstract}
Background: Intertrochanteric femur fractures account half of the hip fractures in elderly, the other majority being neck of femur fracture. 35-40\% of intertrochanteric are unstable (Tronzo's classification type 3, 4 and 5). The dynamic hip screw (DHS) has achieved widespread acclaim in the last few years and is currently considered to be the standard device for outcome assessment. Though, the DHS has been shown to produce good results, but complications are frequent, particularly in unstable inter-trochanteric fracture. The advantage of Proximal Femur Nailing fixation is that it provides a more biomechanically stable construct by reducing the distance between hip joint and implant. The goal of this study is to assess the clinical and radiographical outcomes of the DHS (load bearing implant) and PFN (load sharing implant) for the treatment of Intertrochanteric hip fractures.

Methods: We assessed the same in 52 cases of unstable femur fracture 26 operated with DHS and 26 with PFN and followed up with sequential radiographs for radiological union and sequential interview with Harris hip score calculation for functional outcome assessment.

Results: Patients operated for unstable intertrochanteric femur fracture with Proximal femoral nailing had better Harris hip scores (excellent 4, good 14) compared to dynamic hip screw group (Excellent 6, good 5) and earlier weight bearing (At 18 weeks, $100 \%$ in PFN compared to $65.5 \%$ in DHS). PFN has lesser incidence of postoperative complications (15\% in PFN compared to $38 \%$ in DHS).

Conclusions: The proximal femoral nail has better functional outcome in terms of Harris hip score and early radiologic union in unstable intertrochanteric fractures of femur.
\end{abstract}

Keywords: DHS, PFN, Unstable IT, Harris hip score

\section{INTRODUCTION}

Femoral intertrochanteric fractures are a common fracture of the elderly. In the younger age group of people it is seldom seen, and if it occurs, it is due to high velocity trauma. These fractures account for approximately 50\% the hip fractures in elderly out of which $35-40 \%$ are unstable (Tronzo's classification). ${ }^{1,2}$ Despite development of a variety of implants over the ages, morbidity with this fracture remains high. Non-operative treatment has been found to have a high rate of malunion and co-morbidities. The operative treatment with dynamic hip screw, proximal femoral nail or hemiarthroplasty is prefrreed. ${ }^{3}$ Dynamic hip screw fixation was preferred but lead to more complications in unstable fractures. ${ }^{4}$ Whereas the proximal femoral nailing provides a relatively better biomechanical stability. The ideal internal fixation device should be such that the patient can be mobilized at the earliest without jeopardizing the reduction, stability and union of the fracture. 
This study is an attempt to evaluate and compare the results of operative management of unstable intertrochanteric fractures by the dynamic hip screw and proximal femoral nail in a standardized and objective manner. The main focus in previous controlled studies has been aimed at technique and clinical results, or on the rehabilitation of the patients in general. This is a prospective and randomized study of unstable inter trochanteric fractures treated by operative means by dynamic hip screw (DHS) fixation and proximal femoral nail (PFN) to compare the results and assess when weight bearing starts, union starts and complications.

\section{METHODS}

This is a prospective cohort study of 52 patients having unstable intertrochanteric fracture of femur who were operated by two gold standard operative techniques: Dynamic Hip Screw (26 cases) and Proximal Femoral Nail (26 cases). Period of study was from August 2013 to August 2015 in Surat Municipal Institute of Medical Education and Research, Surat, Gujarat after obtaining necessary ethical approval from institutional ethics committee.

\section{Inclusion criteria}

Inclusion criteria were adults of both sexes; fracture line extending between lesser trochanter and greater trochanter with or without distal extension; no associated vascular injury of the limb; patients giving informed and written consent; no history of reinjury over the vicinity of hip; normal opposite limb; fractures classified according to Tronzo classification and only unstable fractures were taken in study (Tronzo's type 3, 4 and 5).

\section{Exclusion criteria}

Exclusion criteria were pure subtrochanteric fractures or bilateral intertrochanteric fractures; any pathological fracture; compound fracture; poly trauma patient; patient having reinjury at old intertrochnteric fracture site; patients not giving consent.
In all cases pre-operative planning was done. Radiographs of the pelvis with both hips antero-posterior view, lateral view and traction-internal rotation view was obtained to confirm the diagnosis. Selection of which operative method was used on the patient was decided by randomization.

In case of DHS, length of Richard's screw was measured intra operatively with C-arm. Neck shaft angle was measured to determine the angle for barrel plate. Standard non-locking DHS plate with minimum of 6 cortices were fixed to the shaft distal to the fracture. In case of PFN, a long nail with $135^{\circ}$ angle was used in all our cases. The diameter was determined by measuring diameter of the femur at the level of isthmus intra operatively under C-arm. All cases were operated on a single standard fracture table under spinal anaesthesia using standard operating techniques under strict aseptic precautions. C-arm was used in all cases.

Postoperatively, patients' vitals were monitored. Foot end elevation was given. Antibiotics were continued in the post-operative period, I.V for 5 days and oral antibiotics till suture removal (11th day). Patients were taught Static quadriceps exercises, knee bending, ankle pump exercises and chest physiotherapy in the immediate post-operative period. Patient was taught gait training before discharge from the hospital. Only in very unstable fracture patterns weight bearing was not advised. Rest of the patients were encouraged to weight bear partially with axillary crutches or walker depending on the pain tolerability of individual patient.

Follow up was done at 6 weeks, 12 weeks, 6 months, 9 months and 12 months postoperatively to assess the clinical, radiological and functional outcome with the help Harris hip score. ${ }^{5}$ The results were statistically analysed using the chi-square test and $\mathrm{P}$ value of less than 0.05 was taken as significant.

\section{RESULTS}

The observations of 52 cases of unstable intertrochanteric femur fracture showed the following findings.

Table 1: Age and sex distribution of patients.

\begin{tabular}{|c|c|c|c|c|c|c|}
\hline \multicolumn{7}{|c|}{ Age and sex distribution } \\
\hline $\begin{array}{l}\text { Age (in } \\
\text { years) }\end{array}$ & $\begin{array}{l}\text { No. of patients } \\
\text { (DHS) } \\
\text { N }(\%)\end{array}$ & $\begin{array}{l}\text { Male (DHS) } \\
\mathbf{N}(\%)\end{array}$ & $\begin{array}{l}\text { Female (DHS) } \\
\text { N }(\%)\end{array}$ & $\begin{array}{l}\text { No. of patients } \\
\text { (PFN) } \\
\text { N }(\%)\end{array}$ & $\begin{array}{l}\text { Male (PFN) } \\
\mathbf{N}(\%)\end{array}$ & $\begin{array}{l}\text { Female (PFN) } \\
\mathbf{N}(\%)\end{array}$ \\
\hline 21-30 & 0 & 00 & 0 & 0 & 0 & 0 \\
\hline $31-40$ & 0 & 0 & 0 & 0 & 0 & 0 \\
\hline 41-50 & $3(11)$ & $2(11)$ & $1(14)$ & $4(13)$ & $2(12)$ & $1(11)$ \\
\hline $51-60$ & $6(23)$ & $4(21)$ & $1(14)$ & $6(23)$ & $3(18)$ & $1(11)$ \\
\hline 61-70 & $12(46)$ & $9(47)$ & $2(29)$ & $8(32)$ & $5(29)$ & $2(22)$ \\
\hline Above 70 & $5(20)$ & $4(21)$ & $3(43)$ & $8(32)$ & $7(41)$ & $5(56)$ \\
\hline \multirow{2}{*}{ Total } & \multirow{2}{*}{$26(100)$} & $19(73)$ & $7(27)$ & \multirow{2}{*}{$26(100)$} & $17(65)$ & $9(35)$ \\
\hline & & $26(100)$ & & & $26(100)$ & \\
\hline
\end{tabular}


The age distribution of cases of both sexes ranged from 41 to 90 years (Table 1). In the DHS group, maximum 12 $(46 \%)$ number of patients were of age group 61 to 70 years and minimum $3(11 \%)$ were of age group 41 to 50 years. In the PFN group, maximum $8(32 \%)$ number of patients were of age group 61 to 70 years and minimum 4 (16\%) patients were of age group 41 to 50 years. In the DHS group $73 \%$ of the patients were male and $27 \%$ were female. In the PFN group $65 \%$ of the patients were male and $35 \%$ were female.

Table 2: Operative duration.

\begin{tabular}{|llll|}
\hline $\begin{array}{l}\text { Time of } \\
\text { procedure }\end{array}$ & DHS & PFN & Percentage $(\%)$ \\
\hline $\mathbf{0 - 1} \mathbf{h r}<$ & 0 & 0 & 0 \\
\hline $\mathbf{1 - 2} \mathbf{h r}<$ & 17 & 23 & $40(77)$ \\
\hline $\mathbf{2 - 3} \mathbf{~ h r}$ & 9 & 3 & $12(23)$ \\
\hline Total & 26 & 26 & $52(100)$ \\
\hline
\end{tabular}

Majority $32(62 \%)$ of the 52 intertrochanteric fractures occurred following trivial trauma usually a domestic accident like fall in bathroom or fall from stairs while 20 $(38 \%)$ occurred following road traffic accident. Operative duration (Table 2) in $17(65 \%)$ cases of DHS and 23 (88\%) cases of PFN was around 1-2 hours. While it's was 2-3 hours in $9(35 \%)$ cases of DHS as compared to only 3 (12\%) cases of. None of the patients in either group required a operative time of more than 3 hours. Reduction was achieved by closed methods in 24 (92\%) while 2 (4\%) needed open reduction in DHS group. And reduction was achieved by closed methods in $26(100 \%)$ in PFN group. In DHS group $13(50 \%)$ were discharged by $10^{\text {th }}$ day and rest $13(50 \%)$ by next 10 days. In PFN group $16(61 \%)$ were discharged by $10^{\text {th }}$ postoperative day and rest $10(39 \%)$ by next 10 days.

Table 3: Complications in DHS and PFN.

\begin{tabular}{|lll|}
\hline Complications & DHS & PFN \\
B $(\%)$ & N $(\%)$ \\
\hline Backout & $1(4)$ & $1(4)$ \\
\hline Peri implant fracture & 0 & 0 \\
\hline Implant failure & 0 & $1(4)$ \\
\hline Nonunion & 0 & 0 \\
\hline Malunion & 0 & 0 \\
\hline Shortening & $6(23)$ & $1(4)$ \\
\hline Infection & $1(4)$ & 0 \\
\hline AVN & $2(8)$ & 0 \\
\hline Varus & 0 & $1(4)$ \\
\hline
\end{tabular}

Fewer complications occurred in PFN group than DHS group (Table 3). In the DHS group, total number of complications was 10 (39\%). More than one complication occurred in the patients with infection and the total number of such patients with complications was 9 (35\%). In the PFN group, total number of patients with complications was $2(8 \%)$. More than one complication occurred in the same patient. The total number of complications seen was four. Incidence of complications related to implant back out correlated with patient specific factors, such as advanced age and presence of osteoporosis, irrespective of the type of implant used. Infection occurred in the presence of treatment specific variable such as increased operative time. Majority 48 $(92 \%)$ had follow up to 18 months after surgery.

Table 4: Starting full weight bearing.

\begin{tabular}{|llll|}
\hline Weeks & $\begin{array}{l}\text { DHS } \\
\text { N }(\%)\end{array}$ & $\begin{array}{l}\text { PFN } \\
\text { N }(\%)\end{array}$ & $\begin{array}{l}\text { Percentage } \\
(\%)\end{array}$ \\
\hline 0 t0 6 & 0 & 0 & O \\
\hline $\mathbf{7 ~ t o ~ 1 2 ~}$ & $9(34.5)$ & $19(73)$ & $28(54)$ \\
\hline $\mathbf{1 3}$ to 18 & $8(31)$ & $7(27)$ & $15(29)$ \\
\hline$>\mathbf{1 8}$ & $9(34.5)$ & 0 & $9(17)$ \\
\hline Total & $26(100)$ & $26(100)$ & $52(100)$ \\
\hline
\end{tabular}

Partial weight bearing was allowed in $8(31 \%)$ of the patients within 6 weeks of surgery, while $18(69 \%)$ of the patients after 6 weeks of surgery in the DHS group. In the PFN group 14 (54\%) of the patients were allowed to partial weight bear within 6 weeks of surgery, while 12 $(46 \%)$ of the patients after 6 weeks of surgery. Full weight bearing (Table 4) was allowed in $34.5 \%$ of the patients within 12 weeks after surgery, whereas $65.5 \%$ of the patients were allowed after 12 weeks of surgery in DHS group. While $73 \%$ was allowed full weight bearing within 12 weeks after surgery, whereas $27 \%$ of patients were allowed after 12 weeks after surgery in PFN group.

Table 5: Fracture line visibility (6 weeks).

\begin{tabular}{|llll|}
\hline $\begin{array}{l}\text { Fracture } \\
\text { line }\end{array}$ & DHS & PFN & $\begin{array}{l}\text { Percentage } \\
(\%)\end{array}$ \\
\hline Visible & $11(42)$ & $8(31)$ & $19(36)$ \\
\hline Not visible & $15(58)$ & $18(69)$ & $33(54)$ \\
\hline Total & $26(100)$ & $26(100)$ & $52(100)$ \\
\hline
\end{tabular}

Table 6: Position of proximal screw in final follow up.

\begin{tabular}{|llll|}
\hline $\begin{array}{l}\text { Implant } \\
\text { position }\end{array}$ & $\begin{array}{l}\text { DHS } \\
\text { N } \%)\end{array}$ & $\begin{array}{l}\text { PFN } \\
\text { N } \%)\end{array}$ & $\begin{array}{l}\text { Percentage } \\
(\%)\end{array}$ \\
\hline $\begin{array}{l}\text { Implant } \\
\text { in situ }\end{array}$ & $17(65)$ & $21(81)$ & $38(73)$ \\
\hline Cut through & $2(8)$ & 0 & $2(4)$ \\
\hline $\begin{array}{l}\text { Migration } \\
\text { to joint }\end{array}$ & 0 & 0 & 0 \\
\hline $\begin{array}{l}\text { Backing out } \\
\text { of hip screw }\end{array}$ & $7(27)$ & $5(19)$ & $12(23)$ \\
\hline Total & $26(100$ & $26(100)$ & $52(100)$ \\
\hline
\end{tabular}

Fracture line visibility was checked for radiological union by radiographs at 6 weeks (Table 5). In DHS group, the fracture line was visible in X-rays in $42 \%$ of patients, while $58 \%$ showed radiological union at six weeks. In PFN group, the fracture line was visible in X-rays in $31 \%$ of patients, while $69 \%$ showed radiological union at six 
weeks. Radiographs were done at final follow up to check the position of proximal screw (Table 6). In DHS group $17(65 \%)$ had implant in situ, $2(8 \%)$ had screw cut through and $7(27 \%)$ had backing out of screw. In PFN group $21(81 \%)$ had implant in situ while $5(19 \%)$ had screw back out.

Pain at hip was accessed at final follow up using the Harris hip score (Table 7). In the DHS group majority of patients $73 \%$ had none or slight pain at hip, while $19 \%$ had some (mild or moderate) pain at final follow up, and $8 \%$ patients had intolerable pain. While in the PFN group $88 \%$ had none or slight pain at hip at final follow up, while $8 \%$ had some (mild or moderate) pain and $4 \%$ patients had intolerable pain the final follow up. Also the walking ability at final follow up was checked (Table 8). In the DHS group, $39 \%$ were able to walk unlimited and $34 \%$ were confined indoors. In the PFN group, $58 \%$ were able to walk unlimited and $15 \%$ were confined indoors.

Table 7: Pain in hip at final follow up (Harris hip score).

\begin{tabular}{|llll|}
\hline Pain at hip & $\begin{array}{l}\text { DHS } \\
\text { N }(\%)\end{array}$ & $\begin{array}{l}\text { PFN } \\
\text { N }(\%)\end{array}$ & $\begin{array}{l}\text { Percentage } \\
(\%)\end{array}$ \\
\hline None & $8(31)$ & $5(19)$ & $13(25)$ \\
\hline Slight & $11(42)$ & $18(69)$ & $29(56)$ \\
\hline Mild & $4(15)$ & $2(8)$ & $6(11)$ \\
\hline Moderate & $1(4)$ & 0 & $1(2)$ \\
\hline Marked & $2(8)$ & $1(4)$ & $3(6)$ \\
\hline Disabled & 0 & 0 & 0 \\
\hline Total & $26(100)$ & $26(100)$ & $52(100)$ \\
\hline
\end{tabular}

Table 8: Walking ability at final follow up (Harris hip score).

\begin{tabular}{|llll|}
\hline $\begin{array}{l}\text { Distance } \\
\text { walked }\end{array}$ & $\begin{array}{l}\text { DHS } \\
\text { N }(\%)\end{array}$ & $\begin{array}{l}\text { PFN } \\
\text { N }(\%)\end{array}$ & $\begin{array}{l}\text { Percentage } \\
(\%)\end{array}$ \\
\hline Unlimited & $10(39)$ & $15(58)$ & $25(48)$ \\
\hline 6-4 blocks* & $4(16)$ & $4(16)$ & $8(16)$ \\
\hline 2-3 blocks** & $3(11)$ & $3(11)$ & $6(11)$ \\
\hline Indoors only & $9(34)$ & $3(11)$ & $12(23)$ \\
\hline Bed and chair & 0 & $1(4)$ & $1(2)$ \\
\hline Total & $26(100)$ & $26(100)$ & $52(100)$ \\
\hline
\end{tabular}

$* 3$ blocks is 500 meters; $* * 6$ blocks is 1 kilometer.

Crossed leg sitting and squatting were checked at final follow up (Table 9). In the DHS group 38\% of the patients were able to sit cross legged, $58 \%$ found it difficult to sit cross legged, whereas, $4 \%$ were unable to do so mainly because of pain at hip. In the PFN group $15 \%$ of patients were able to sit cross-legged, 77 found it difficult to sit cross legged, where as $6 \%$ were unable to do so mainly because of pain at hip. In the DHS group $23 \%$ of patients were able to squat without difficulty, $69 \%$ found it difficult to squat, whereas $8 \%$ were unable to do so mainly because of pain at hip. In the PFN group $46 \%$ of patients were able to squat without difficulty, $46 \%$ found it difficult to squat, whereas $8 \%$ were unable to do so mainly because of pain at hip.

The final functional outcome of the patients of both the groups was measured using the Harris hip score (Table 10). In the DHS group $23 \%$ of the patients had excellent functional results on final follow up and $8 \%$ had poor functional results on final follow up. In the PFN group $15 \%$ had excellent functional results on final follow up and $4 \%$ had poor functional results on follow up.

Table 9: Sitting crossed legs and squatting ability at final follow up (Harris hip score).

\begin{tabular}{|c|c|c|c|c|c|c|}
\hline \multirow[b]{2}{*}{ Difficulty level } & \multicolumn{3}{|c|}{ Sitting crossed legs } & \multicolumn{3}{|c|}{ Squatting } \\
\hline & $\begin{array}{l}\text { DHS } \\
\text { N }(\%)\end{array}$ & $\begin{array}{l}\text { PFN } \\
\text { N (\%) }\end{array}$ & $\%$ & $\begin{array}{l}\text { DHS } \\
\text { N }(\%)\end{array}$ & $\begin{array}{l}\text { PFN } \\
\text { N }(\%)\end{array}$ & $\%$ \\
\hline Without difficulty & $10(38)$ & $4(15)$ & $14(27)$ & $6(23)$ & $12(46)$ & $18(34)$ \\
\hline With difficulty & $15(58)$ & $20(77)$ & $35(67)$ & $18(69)$ & $12(46)$ & $30(58)$ \\
\hline Unable & $1(4)$ & $2(8)$ & $3(6)$ & $2(8)$ & $2(8)$ & $4(8)$ \\
\hline Total & $26(100)$ & $26(100)$ & $52(100)$ & $26(100)$ & $26(100)$ & $52(100)$ \\
\hline
\end{tabular}

Table 10: Functional result in present study (according to Harris hip score).

\begin{tabular}{|lllll|}
\hline Clinical results & Points & DHS & PFN & Percentage $(\%)$ \\
\hline Excellent & $90-100$ & $6(23)$ & $4(15)$ & $10(19)$ \\
\hline Good & $80-89$ & $5(19)$ & $14(54)$ & $19(37)$ \\
\hline Fair & $70-79$ & $13(50)$ & $7(27)$ & $20(38)$ \\
\hline Poor & $<70$ & $2(8)$ & $1(4)$ & $3(6)$ \\
\hline & Total & $26(100)$ & $26(100)$ & $52(100)$ \\
\hline
\end{tabular}




\section{DISCUSSION}

In this study an attempt was made to survey, evaluate, document and quantify our success in the management of such individuals by using PFN and DHS implants and compare the result in these two groups.

In present study majority cases were between 61-70 age group which is comparable to Pan et al. ${ }^{6}$ But other study by Saudan et al and Pajarinen et al concludes higher age group. ${ }^{7,8}$ This may be due to lesser life expectancy in India. There was a male preponderance in our patients, while this coincides with the above mentioned study but is quite different from the other studies wherein there has been an evident female preponderance. Cleveland et al in their study had $87.7 \%$ of female patients with the reason attributed to higher incidence of coxa vara in this sex as well as attribution to senile osteoporosis. ${ }^{9}$

Present study has domestic fall as a more common mode of injury than road traffic accident. This may be attributed to the following factors as enumerated by Cummings et al in 1994 such as inadequate protective reflexes to reduce energy of fall below a certain critical threshold, inadequate local shock absorbers e.g. muscle and fat around hip and inadequate bone strength at the hip on account of osteoporosis or osteomalacia. ${ }^{10}$ Intertrochanteric femur fractures in young are more common due to road traffic accident or fall from height. In our study the average time of surgery in PFN was about 65 minutes and DHS was about 75 minutes which is comparable to study by Pan et al and Giraud et al. ${ }^{6,11}$ There was average 150-250 $\mathrm{ml}$ of blood loss in DHS group as compared to $100-150 \mathrm{ml}$ in PFN group in our study. Similar studies by Pan et al and Liu et al further signifies more blood loss during DHS. ${ }^{6,12}$

We had more complications in DHS group as compared to PFN group which is comparable to studies by Saudan et al and Liu et al. ${ }^{7,12}$ We had 1 case of infection in DHS group but it was not deep seated so was managed with continued use of IV antibiotics for 10 days. In the series of patients operated by DHS by Kulkarni et al, there were two cases of deep infection which were treated by removal of implant. ${ }^{13} \mathrm{We}$ had limb shortening in 1 case of PFN group and in 6 cases of DHS group ranging from 1 to 1.5 centimeter. In the series by Harrington et al out of 72 cases there were 4 cases of coxavara and 56 cases of limb shortening at an average of $1.5 \mathrm{cms}^{14}$ In his series, shortening was noted in unstable fractures in which Dimon-Hughston procedure was done. In the series by Rao et al of 124 cases of intertrochanteric fractures, 5 cases of unstable fracture had limb shortening. ${ }^{15}$ No radiological complication of $\mathrm{Z}$ effect or reverse $\mathrm{Z}$ effect was seen in the PFN group.

Average time of union in all our cases was about 17 weeks (ranging from 15 to 20 weeks). We have used criteria for union as presence of bridging callus formation at fracture site. Most of the fracture circumference with density similar to adjacent cortical bone. Clinically absence of pain at fracture site. This is similar to studies by Harrington et al and Rao et al. ${ }^{14,15}$

In our study $23 \%$ of the patients had excellent functional results on final follow up, $19 \%$ had good results, $50 \%$ had fair results and $8 \%$ had poor functional results on final follow up, in the DHS group. In the PFN group, $15 \%$ had excellent functional results on final follow up, $54 \%$ had good results, $27 \%$ had fair and $4 \%$ had poor functional results on follow up. This is similar to the results obtained by Pan et al, Giraud et al and Gupta et al. ${ }^{6,11,16}$

\section{CONCLUSION}

Looking at the results we found that patients treated with proximal femoral nail had better outcome in terms of shorter operative time, less operative blood loss, relatively smaller incision, relatively shorter hospital stay, less complications, early mobilization in terms of early partial and full weight bearing and a better functional outcome on the basis of Harris Hip score at final follow up as compared to patients treated with dynamic hip screw.

Thus, from our study Proximal Femoral Nail proves to be a better implant and has an edge over Dynamic Hip Screw in the management of unstable intertrochanteric fractures of femur.

\section{Funding: No funding sources}

Conflict of interest: None declared

Ethical approval: The study was approved by the institutional ethics committee

\section{REFERENCES}

1. Tronzo RG. Symposium on fractures of the hip. Special considerations in management. Orthop Clin North Am. 1974;5(3):571-83.

2. Sidhu AS, Singh AP, Singh S. Total hip replacement as primary treatment of unstable intertrochanteric fractures in elderly patients. Int Orthop. 2010;34(6):789-92.

3. Grimsrud C, Monzon RJ, Richman J, Ries MD. Cemented hip arthroplasty with a novel cerclage cable technique for unstable intertrochanteric hip fractures. J Arthroplasty. 2005;20(3):337-43.

4. Kim WY, Han CH, Park JI, Kim JY. Failure of intertrochanteric fracture fixation with a dynamic hip screw in relation to pre-operative fracture stability and osteoporosis. Int Orthop. 2001;25(6):360-2.

5. Harris WH. Traumatic arthritis of the hip after dislocation and acetabular fractures:treatment by mold arthroplasty. An end-result study using a new method of result evaluation. J Bone Joint Surg Am. 1969;51(4):737-55.

6. Pan XH, Xiao DM, Lin B, Huang G. Dynamic hip screws (DHS) and proximal femoral nails (PFN) in 
treatment of intertrochanteric fractures of femur in elderly patients. Chinese J Orthop Trauma. 2004;6(7):785-9.

7. Saudan M, Lübbeke A, Sadowski C, Riand N, Stern R, Hoffmeyer P. Pertrochanteric fractures:is there an advantage to an intramedullary nail?:a randomized, prospective study of 206 patients comparing the dynamic hip screw and proximal femoral nail. J Orthop Trauma. 2002;16(6):386-93.

8. Pajarinen J, Lindahl J, Michelsson O, Savolainen V, Hirvensalo E. Pertrochanteric femoral fractures treated with a dynamic hip screw or a proximal femoral nail:a randomised study comparing postoperative rehabilitation. J Bone Joint Surg. British volume. 2005;87(1):76-81.

9. Cleveland M, Bosworth DM, Thompson FR, Wilson HJ, Ishizuka T. A ten-year analysis of intertrochanteric fractures of the femur. J Bone Joint Surg. 1959;41(8):1399-408.

10. Cummings SR, Nevitt MC. Non- skeletal determinants of fractures:the potential importance of mechanics of falls. Osteoporosis Int. 1994;4(1):6770 .

11. Giraud B, Dehoux E, Jovenin N, Madi K, Harisboure A, Usandizaga G, et al. Pertrochanteric fractures:a randomized prospective study comparing dynamic screw plate and intramedullary fixation.
Revue de Chirurgie Orthop Et Reparatrice De L'appareil Moteur. 2005;91(8):732-6.

12. Liu XW, Zhang CC, Su JC, Fu QG, Yu BQ, Xu SG. Treatment of trochanteric fractures of eldly with dynamic hip screwand proximal femoral nail (single center, randomized and prospective research). Chinese J Bone Joint Injury Chinese. 2009;24(9):796-7.

13. Kulkarni GS. Treatment of trochanteric fractures of the hip by modified Richard's compressing and collapsing screw. Indian J Orthop. 1984;18(1):30-4.

14. Harrington KD, Johnston JO. The management of comminuted Unstable Intertrochanteric Fractures. J Bone Joint Surg. 1973;55:1367-76.

15. Rao JP, Banzon MT, Wiess AB. Treatment of unstable intertrochanteric fracture with anatomic reduction and compression hip screw. Clin Orthop Rel Res. 1983;(175):65-71.

16. Venkatesh Gupta SK, Valisetti VS. Comparative study between dynamic hip screw vs proximal femoral nailing in inter-trochanteric fractures of the femur in adults. Int J Orthop Sci. 2015;1(1):7-11.

Cite this article as: Parikh KN, Parmar C, Patel M, Shah SB. Functional and radiological outcome of proximal femoral nailing versus dynamic hip screw in unstable intertrochanteric femur fractures. Int J Res Orthop 2018;4:861-6. 